\title{
Economy of Knowledge and Economic Growth in Russia
}

\author{
Olga Rudakova \\ Financial University under the Government of the Russian Federation \\ Moscow, Russia \\ E-mail: olrud@yandex.ru
}

\begin{abstract}
The article shows the role of the education system in the formation of the economy of knowledge, which should ensure economic growth. The author outlines the main aspects of state policy in order to form economy of knowledge.
\end{abstract}

Keywords-economy of knowledge; education system; innovations; economic growth

\section{INTRODUCTION}

Development of modern knowledge has become one of the main factors of boosting of the economic growth and social development in the current environment. Special attention should be given to the advent of the economy of knowledge, through active management of knowledge, creation and development of the knowledge exchange programmes, cooperation of the creative teams within innovative projects and creation of resources for the successful implementation of such projects.

Economic policy plays a crucial role in the development of the process of innovation, while the latter (alongside distribution of knowledge) require firm scientific foundation and system of scientific-research institutes, which serve as clusters of cooperation between the scientific community and manufacturing sector.

\section{RUSSIAN ECONOMY AND THE ECONOMY OF KNOWLEDGE}

It is important to conduct proper analysis of the role of investments into scientific research, $R \& D$ and its correlation with the increase in profitability of companies, as well as to consider the national priorities of state-funded programmes in the US, EU and Asia in the field of fundamental and applied sciences which are of paramount importance for the national security, rapid development of competitiveness of the national economies. Methods of strategic planning, forecasting and resource distribution that lay at the heart of such programmes should also be given a thorough consideration.

Russian economy has not yet become fully receptive in adoption of the up-to-date scientific and technical achievements. Considerable part of the manufacturing companies fails to invest properly into creation of new technologies and/or modernization of the existing that leads to a minimal 2-generation lag in technological advancement in scientific equipment. As a result the development laboratories have not only decreased in absolute numbers, but also lost a hefty portion of their human and material capital. Private (or corporate) sector of innovation has been limited to a number of niche segments so that the average share of innovative element in most of the industrial products has fallen to as low as $1 \%$ of sales value. Compared with the number of industrial research companies in the US, Japan, EU and even China, where the share of such companies is around $60 \%$, the Russian sector can boast of a meager $6 \%$.

Recent surveys reveal that the efficiency of application of resources in Russia's economy is $25 \%$ for natural resources, $15 \%$ for human capital, $10 \%$ for financial and only $3.3 \%$ for intellectual. The overall level of resource application in Russia is only $18 \%$ m compared with $76 \%$ in the US, $78 \%$ in the EU and $88 \%$ in Japan. [4]

Given the current environment the Russian industrial policy must have a two-fold objective: first and foremost it is important to conduct the modernization of economy via solving its current problems and boosting economic growth and, secondly, it is vital to determine the long-term strategy for the economic development of the country.

The Russian share of high-tech products in the total volume of produce in the in global market is estimated by experts to be between $0.3 \%-0.8 \%$, that is 8.5 times lower compared with the share of Russia's GDP in the global GDP. Russia's export of innovations is 130 times lower than that of the US, as the share of the relevant companies in Russia is only $9.3 \%$ out of total industrial companies. Thus is would be true to say that 9 out of 10 Russian companies somehow manage to conduct operational activity without any innovative component at all. [2] This is aggravated by the fact that Russian companies, compared with western peers, are quite reluctant to purchase new technologies, that is driven by the relative conservatism in management, local customs (i.e. to work under a pre-defined set of rules) as well as simple fear of anything new - lack of innovative consciousness. Most of the managers think that it is much easier to import a new car rather then conduct a technological upgrade of own equipment to have such car developed. 
TABLE I. InNOvative ACTIVITIES IN RUSSIA AND IN THE EU [5]

\begin{tabular}{|c|c|c|c|c|c|}
\hline & Russia & $\begin{array}{l}\text { Industrial leaders: } \\
\text { Denmark }\end{array}$ & $\begin{array}{c}\text { Industrial near-leaders: } \\
\text { Belgium }\end{array}$ & $\begin{array}{l}\text { "Shy" pioneers: } \\
\text { Czech Republic }\end{array}$ & $\begin{array}{c}\text { Low-performers: } \\
\text { Bulgaria }\end{array}$ \\
\hline $\begin{array}{l}\text { Share of employees in the innovation- } \\
\text { active enterprises, } \%\end{array}$ & 36,0 & 52 & 51 & 41 & 16 \\
\hline $\begin{array}{l}\text { Share of Revenue of the innovation- } \\
\text { active enterprises compared with total } \\
\text { Revenue, } \%\end{array}$ & 48,0 & 83 & 80,7 & 65,6 & 39,7 \\
\hline $\begin{array}{l}\text { Share of high-tech produce in the total } \\
\text { value of industrial export, } \%\end{array}$ & 9,0 & 20,0 & 8,0 & 14,0 & 6,0 \\
\hline $\begin{array}{l}\text { Share of innovative produce in the total } \\
\text { revenue, } \%\end{array}$ & 5,5 & 16,1 & 17,8 & 25,1 & 36,2 \\
\hline $\begin{array}{l}\text { Share of innovation costs in the overall } \\
\text { cost of produce, } \%\end{array}$ & 1,44 & 3,81 & 4,09 & 2,69 & 0,89 \\
\hline
\end{tabular}

The economy based on the vast industrial manufacturing with mass production in heavy industries is being substituted by the advent of economy based on the intellectual labour and human capital. The role of an employee is becoming more and more important, leading to such positive social shift as huge role of education, overall increase in the cultural development and wealth of employees who are involved in the intellectual labour.

One of the key peculiarities of Russia is that the shift from the soviet economy to market economy was based on the misconception that the society was ready for such a shift, while in real life the Russian society was still trapped in the archaic consciousness of the traditional society. This leads to the painful situation when the legal balances, intrinsic for the modern capitalism, are not fully functional, while the traditional forms (moral value, moral balances) have been rendered null and void, leaving much of the population in a vacuum.

Tackling the matter of creation of the economy of knowledge in Russia it is vital to understand that the country still faces significant problems not only with the innovative development, but simply with industrial reproduction, as the amortization levels in most of the industries has reached $80 \%$. Thus legal, institutional and economic measures should be undertaken by the state, that has a definite vested interest in the development of the economy of knowledge. Tax benefits, similar to those in the US and UK, could also have a positive impact on the above process. However, at this stage only $1.6 \%$ of Russia's GDP is reinvested into manufacturing of knowledge, while in the OECD the figure is $5 \%$. The key reason is that a major shift in mindset is necessary so that human capital, not natural resources, would be put as the pillar of economic strength of the state.

Approximately $25 \%$ of workforce in the developed countries is employed in the research and development and innovation departments. Roughly $8 \%$ of population of the US create more than $20 \%$ of the country's GDP, while the average spending on research and development and innovation in the US is close to $40 \%$ of total global spending in the area. More than $66 \%$ of the employed have higher education or bachelor degree (the current US administration intends to bring this level to as high as $90 \%$ within the current generation). The same parameters for Russia are: $2.5 \%$ of world's population, $2.5 \%$ share in global GDP, while research and development expenditure is much smaller
$-1 \%$, with the human factor growing as the reason for a great number of technological catastrophes, i.e. the employees are too incompetent or unable to operate modern equipment.

There have been certain positive developments in this field in Russia during the last years: in the year 2000, 22 out of 100 employees had higher education, while in 2015 the figure reached 32. At current pace the level of employees with higher education would climb to $50 \%$ by the end of 2025, making Russia one of the leading global economies based on the number of employees with higher education, since the latter should be viewed as one of the economic growth factors for the next decade [3]. This is triggered by the fact that most of employers appear to be determined to give preference to applicants with higher education, that can be accounted for by the fact that higher education helps an individual to form his/her cultural and professional competencies, that create certain positive attitude towards working process, ability for self-education and constant selfdevelopment and easier adaptation to the ever-changing environment.

Russia currently lags 2-3 times by the average size of investment into the economy of knowledge compared with average global rate, since the private capital does not treat such investment as inherent part of their business (while private investments in the EU reach $55 \%$ and $67 \%$ in the US).

The country still fails to capitalize on the lesson it has learned so many times over the last years, i.e. any institution that is involved in manufacturing of knowledge that has proper tax benefits can exponentially boost production of knowledge. Distinguishing from the conventional markets, the results of the economy of knowledge cannot be tested in the open market to understand the market sentiment, as the market is based on the reputation and trust, rather than the quality of the final produce.

\section{STATE POLICY AND THE ECONOMY OF KNOWLEDGE}

One can identify three major aspects when looking at the state policy in the field of the economy of knowledge. Firstly, this is the transformation of the institutional background of science, where the state must play the leading role up to the moment of the advent of top-quality corporate science, that is already happening. Secondly, it is vital to shift from directed support aimed at particular enterprises to the approach based 
on the industry and activity. This remains an acute challenge as the state somehow continues to support particular enterprises, institutes and programmes. For instance, one can consider the Law on Science, which is concentrated on the direct support of particular science clusters and enterprises, while scientific activity in the universities and corporations is fairly discriminated. Thirdly, it is important to stimulate all forms of cooperation between various types of scientific institutions and programmes, e.g. between science, education and business via support of business clusters and other similar institutions.

Cast lag in the technological development of Russia can be also accounted for by improper management technics, which had formed well before the shift to the market economy and which is being put in motion notwithstanding the growing demand that has been presented by the market environment, the realities of globalization and integration of Russia's economy into the global market.

The state (via its governmental institutions) can play a crucial role in the new economy, which should be based on the model of open market and innovation, however this is a U-turn shift in the standard activity that the authorities have become used to undertake. Firstly, the state can participate in financing during the first stages of research and development, and invest in education, playing a significant role in the institutional/legal protection of the intellectual property. The latter should be transparent so that any company would be sure that its intellectual property is institutionally protected by law. The state should also facilitate the exchange of knowledge, results of research, information and technologies, by such simple actions as setting up conferences, tenders and other. Small businesses should also receive state aid since it is more exposed to market volatility however is much more flexible compared with corporate or state enterprises.

\section{NATIONAL EDUCATIONAL SYSTEM AND THE ECONOMY OF KNOWLEDGE}

Such strategic choice is deemed to be made by a country's current ruling elite, with the national educational system standing at the heart of the process. The latter, one the one hand, creates resources for new technologies, while also contributing to the formation of the national elite, i.e. competent, dedicated and moral powers, which can transform the country into the new shape.

Educational system generally creates the key factor of the economic growth that is intellectual resources, which possess sufficient technological knowledge and practical skills and are able to constantly upgrade them.

Development of the new technological principles of management and technologies themselves can be done only via new approach towards consciousness and behavioral concepts, which should be translated via the new system of promotion of human capital. Thus national educational system must be fully integrated into the global technological race. US studies in social psychology reveal that "amortization" of knowledge occurs every 18 months, triggering the necessity for renovation and perfection. [1] Drive for the constant life-long self-education has evolved into the LifeLong Learning (LLL) trend. Russian analysts say that only $10 \%$ of employees in Russia who are older than 40 years are engaged in any educational programmes, while the same figure for Germany is $40 \$$ and almost as high as $60 \%$ for Sweden. On the one hand this is the direct sign of Russia's lag, however on the other hand it indicates the direction of the currently contemplated changes [3]. The above process may well result in further commercialization of the post-graduate education, with broader palette of business-projects at all possible levels: from a separate oneoff course or consultation and up to a vast online platforms and off-line education centers, all of which would be on the commercial basis.

One can identify the following factors that would be driving the educational system of the next 25 years: (a) qualitative changes in the human capital potential; (b) extension of longevity of population; (c) constant shift in technologies, some of which would be fully transformed within a lifetime of a single generation; (d) boost in the purchasing power of population; (e) further globalization of the English language as professional and business language.

Educational system, that reproduces and transforms culture as combination of values, beliefs and norms of behavior is the key element to both social sustainability and development. It has special importance when two major resources of the information society, namely financial and intellectual resources, reach unprecedented mobility and effectively become ex-territorial, constantly migrating between countries and even whole regions of the planet. Given the latter the existing elites of successful countries (which effectively control the lion's share of most of resources) enhance the sense of cultural and national identity of their countries and populations. Elites of other nations, which lose the sense of national identity tend to act against the national interests. Therefore the system of national education is called upon to strengthen the competitiveness of national cultures since the advent of new technologies requires stronger, more profound cultural elements and background.

Education is one of the most powerful communication channels within a society. The quantity and composition of information in the ever-changing economy drives the need for the fast and deep economic transformations. The higher the rate and depth of modernization, the bigger should grow the communication budgets and programmes. The latter should be aimed at risk mitigation and minimization, especially of those risks that result in the decrease of the manageability of economic systems during modernization. Misevaluation of the importance of communication programmes may well lead to new crisis and even catastrophes. It is important tht the communication groprammes that are implemented in a given society via different channels should be integrated into the single approach.

Basing our assumptions on the above theoretical background one can clearly identify the problems and challenges of Russian educational system as well as dig out the pattern for its strategic development. 
It is common knowledge that the Soviet secondary-level education as well as higher education in the field of natural and industrial sciences were the world's best, with its expertise being widely used by USA, Japan and China.

During the 1990-s the country lost a number of critically important technologies, experienced decrease in industrial manufacturing, that led to growth in share of mining industries and lower spending on education on all social levels. There was little demand for new technologies and qualified research and technical employees. The overall cultural level as well as quality of national education experienced similar downward trend. Quality of state management also decreased, including the quality of government management of educational system. This created a vicious circle that prevented translation to innovative economy based on knowledge and growth in the future.

Russian educational system must concentrate on preparation of scientists, managers and multi-purpose specialists with creative ability, who would be capable of: (a) managing the existing products and technologies; (b) borrow and re-engineer the existing global technologies and products and (c) develop their own technological principles and technologies. Each layer of economy should have its own "production" chain of education, starting with schools and colleges and up to universities, with regional clusters being at the forefront of the regional and federal innovation centers.

Top Russian educational establishments (on all layers) should become elite based on the quality of education and accessibility to the talented and gifted young, being effectively free for students (as it happens in the top international universities at the moment).

Future engineers and research specialists should have assignments with top international technological corporations, similar to the practice of the 1920-s when the "young" Soviet state was sending out talented youth to the best international centers (Reserford in England, Curie in France and Bor in Denmark). It was that youth that created most of the Russian fundamental research facilities and laid foundation for a scientific breakthrough that led to the creation of nuclear bombs and helped to gain access to space.

In some industries the bachelor system deems to be more reasonable in case the graduates are specialized in diverse fields (like the engineers and technicians in the US). It is important to recreate such cooperation between the universities, Russian Academy of science and industrialbased R\&D enterprises, as well as develop "entrepreneurial" universities for faster implementation of new technologies into real sectors of the economy.

The new vision for the university of the future is being discussed nowadays (which is sometimes referred to as University 3.0) and can be defined as not a start-up cluster, but rather a keeper of cultural identity and manufacture of the reason of life. Moreover, the currently existing higher educational establishments would define the future of state management in the country as they are currently involved in education of the future politicians. Thus universities can become the centers of transformation of the economic and political life in the country, as well as its industries, regions and populations.

\section{CONCLUSION}

The strategy of development of system of education is the cornerstone of the future success of Russia as a state as it would lay foundation to the new technological breakthrough that would boost the quality of life for citizens, while failure to do so would inevitably result in Russia's economy turning into the low manpower productivity and low living standards.

We are of opinion that success in doing so would enable serial constant and tailored modernization steps that would consolidate the society on the basis of common vision of its future and positive results of such vision. Thus the decision in the sphere of education would be the decisive factor for our future in the decades to come.

\section{REFERENCES}

[1] Blinov A.O. Problems of Russian education in the 21st century URL: http://www.baltic-course.com/eng/kruglij_stol/?doc $=49552$

[2] Blinov A.O., Rudakova O.S. Formation and development of the creative potential of modern organizations in Russia URL: http://www.baltic-course.com/eng/kruglij_stol/\&doc=13914

[3] Experts of the Gaidar Forum revised the paradigm of higher education.URL: http: //gaidarforum.ru/news/eksperty-gaydarovskogoforuma-peresmotreli-paradigmu-vysshego-obrazovaniya/

[4] National innovation system and state innovation policy of the Russian Federation. Basic report to the OECD review of the national innovation system of the Russian Federation Moscow 2009 URL: http: //www.ifap.ru/library/book449.pdf

[5] Rudakova O.S. Methodology of business processes reengineering of industrial organizations. Abstract of the thesis. Econ. Sciences, Moscow, 2010. 